\title{
Nodulation, gas exchanges and production of peanut cultivated with Bradyrhizobium in soils with different textures
}

\author{
Emanuelle Barros Sobral de Melo', Liziane Maria de Lima², Paulo Ivan Fernandes-Júnior², \\ Saulo de Tarso Aidar ${ }^{3}$, Maria Aline Oliveira Freire², Rosa Maria Mendes Freire², \\ Roseane Cavalcanti dos Santos² \\ 'State University of Paraiba, Campina Grande, PB, Brazil \\ ${ }^{2}$ Brazilian Agricultural Research Corporation - Embrapa Algodão, Campina Grande, PB, Brazil \\ ${ }^{3}$ Brazilian Agricultural Research Corporation - Embrapa Semi-árido, Petrolina, PE, Brazil \\ *Corresponding author, e-mail: roseane.santos@embrapa.br
}

\begin{abstract}
Nitrogen fertilization from biological source is an uncommon practice for peanut growers due to the limited results, mainly in environments with water restriction. In this study, the response of a commercial Bradyrhizobium was evaluated on the nodulation and production of peanuts grown in sandy and medium textured soils. Two experiments using different soils were carried out in the field during the dry season, in Campina Grande, Paraíba State, Brazil. Three peanut genotypes were submitted to the following treatments: 1-no nitrogen fertilization (control), 2- chemical fertilization (ammonium sulfate) and 3- inoculation with Bradyrhizobium [commercial strain BR 1405 (SEMIA 6144)]. A completely randomized $3 \times 3$ factorial design was adopted with five repetitions for both experiments. The evaluates variables were: height of the main stem, number of nodes/plant, root length, root dry weight, weight of pods/plant and number of pods/plant. In addition, gas exchanges were estimated using IRGA apparatus. Both genotypes (BRS Havana and L7 Bege) were benefited in relation to production due to an inoculation with SEMIA 6144. No physiological response was verified in genotypes or $\mathrm{N}$-treatments to gas exchange, excepting for the $\mathrm{Ci} / \mathrm{Ca}$ ratio in the medium textured soil experiment. BRS Havana showed low Ci/Ca ratio in Bradyrhizobium treatment, indicating that SEMIA 6144 improved the plants photosynthetic efficiency.
\end{abstract}

Keywords: Arachis hypogaea, biological nitrogen fixation, soil fertilization, gas exchange.

\section{Nodulação, trocas gasosas e produção do amendoim cultivado com Bradyrhizobium em solos com texturas diferentes}

\section{Resumo}

A adubação nitrogenada por fonte biológica é uma prática raramente adotada por agricultores de amendoim, devido a limitações de informações, principalmente em ambientes com restrição hídrica. Neste trabalho, a resposta de um inoculante comercial de Bradyrhizobium foi avaliada sobre a nodulação e produção de amendoim cultivado em solos arenoso e de textura média. Dois experimentos foram conduzidos em campo durante a estação seca, em Campina Grande, PB, com cada tipo de solo citado. $O$ delineamento adotado foi o inteiramente casualizado com fatorial 3 x 3 e cinco repetições. Três genótipos de amendoim foram submetidos aos seguintes tratamentos: 1-sem adubação nitrogenada (controle), 2-fertilização química (sulfato de amônio) e 3- fertilização biológica [estirpe comercial BR 1405 (SEMIA 6144)-Bradyrhizobium]. As variáveis avaliadas foram: altura da haste principal, número de nódulos/planta, comprimento da raíz, peso seco da raíz, peso das vagens/planta e número de vagens/planta além das trocas gasosas que foram estimadas com o auxílio do equipamento IRGA. Dois genótipos (BRS Havana e L7 Bege) foram beneficiados na produção devido à inoculação com a estirpe SEMIA 6144. Nenhuma resposta fisiológica foi verificada nos genótipos ou nos tratamentos com $\mathrm{N}$ para trocas gasosas, com exceção da relação $\mathrm{Ci} / \mathrm{Ca}$, no experimento em solo de textura média. A BRS Havana apresentou baixa relação Ci/Ca no tratamento com Bradyrhizobium, indicando que SEMIA 6144 melhorou a eficiência fotossintética das plantas.

Palavras-chave: Arachis hypogaea, fixação biológica de nitrogênio, fertilização do solo, trocas gasosas 


\section{Introduction}

Biological nitrogen fixation (BNF) is a natural process that occurs mainly through symbiotic association in legumes species by rhizobial bacteria that convert elemental nitrogen into ammonia. In nature, only a few microorganisms are able to reduce $\mathrm{N}_{2}$ through the nitrogenase complex. Such interaction with plants account for $65 \%$ of the current nitrogen used in agriculture (Jones et al., 2007, Swain \& Abhijita, 2013).

Several bacteria have been used as inoculants to improve the crops fertilization, providing an effective establishment of the nitrogen-fixing symbiosis. In addition to the nitrogen fixation, those bacteria are able to produce several molecules that promote plant growth and grain yield (Hayat et al., 2008). The advantage of this process is the total use of the fixed nitrogen by plants (Epstein \& Bloom, 2006, Swain \& Abhijita, 2013).

BNF varies with soil fertility and temperature, genotypes and Rhizobium strains (Santos et al., 2005; Borges et al., 2007). High soil temperatures in tropical and subtropical climates are a major problem for BNF because it can affect $\mathrm{N}_{2}$ fixation. Critical temperatures for $\mathrm{N}_{2}$ fixation are around $35^{\circ} \mathrm{C}-40^{\circ} \mathrm{C}$ (Nehra et al., 2007, Yadav \& Nehra, 2013).

Peanut (Arachis hypogaea L.) is nodulated by an array of rhizobial species. The route that rhizobia fixes nitrogen is brief: rhizobia initiates the infection at the axils of emerging lateral roots and proliferates in intercellular spaces before entering in cortical cells. Then, rhizobia spreads further through the root cortex via an intercellular matrix and are eventually released into plant cells (Angelini et al., 201 1, Lyra et al., 2013, Ahemad \& Kibret, 2014). Among the bacteria that can nodulate peanut, several are very efficient and the prospection of bacterial isolates to this crop revealed some promising bacteria as new inoculants (Lyra et al., 2013, Torres-Júnior et al., 2014).

Siddique \& Bal (1991) reported that peanut is privileged by $B N F$, since plants are able to maintain nitrogen fixation even with poor supply of photosynthates. This ability is due to the presence of lipid bodies near the periobacteroid membrane. However, since Arachis presents hypogeal fruits, soil sandy texture is more appropriate for the management, although it affects the strains efficiency due to low fertility and water retention (Bolonhezi et al., 2013).

Montans et al. (2008) evaluated the nodulation of peanut, using sandy and clay soils, both without previous cropping and observed that in clay soil plants had high number of nodules with improved strain and no effect in competition was verified between inoculant and native strains.

Despite to evidence of BNF benefits to crops management, there is limited information about the interactions between Bradyrhizobium genotypes and isolates, especially in semiarid regions, where soil and weather conditions may reduce the isolates efficiency. The present study aimed to provide further information about BNF in peanuts focused in different genotypes and soil textures. Nodulation and pod production were estimated based on chemical fertilization and inoculation of a commercial Bradyrhizobium sp. strain.

\section{Material and methods}

Field experiments

The experiments were carried out at Campina Grande, Paraiba State, Brazil $107^{\circ} 13^{\prime} \mathrm{S}$; $35^{\circ} 53^{\prime} \mathrm{W}$ ), during the 2013 dry season (sept/dec), using three upright genotypes, represented by commercial cultivars (BR 1 and BRS Havana), developed to semiarid environment by the Brazilian Agricultural Research Corporation (Embrapa), and a top line (BRS L7 Bege), generated by crossing with African and Brazilian germplasm (Santos et al., 2013). The assays were set up with two different soil samples. The first experiment was installed with a sample of a loamy-sandy Fluvic soil [Neossolo Flúvico] $(\mathrm{pH}$ :

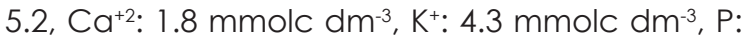
$2.1 \mathrm{mg} \mathrm{dm}^{-3}$ and organic matter: $4.7 \mathrm{~g} \mathrm{~kg}^{-1}$ of soil). This soil presented 777,170 and $53 \mathrm{~g}^{\mathrm{kg}} \mathrm{kg}^{-1}$ of sand, silt and clay, respectively. The second experiment was installed using as substrate a sample of a medium-textured Red-Yellow Ultisol (Argissolo Vermelho-Amarelo) (pH: 5.4, $\mathrm{Ca}^{+2}: 5.4 \mathrm{mmolc} \mathrm{dm}^{-}$ $3, \mathrm{~K}^{+}: 1.8 \mathrm{mmolc} \mathrm{dm}^{-3}, \mathrm{P}: 4.9 \mathrm{mg} \mathrm{dm}^{-3}$ and organic 
matter $14.9 \mathrm{~g} \mathrm{~kg}^{-1}$ of soil). The granulometric analysis presented amounts of 791, 91 and 118 g. $\mathrm{kg}^{-1}$ of sand, silt and clay, respectively. The soils were classified according to Embrapa (2013). Both soils were previously limed and fertilized based on peanut crop demands for the Brazilian Northeast region (Embrapa, 2013).

The average data of temperature and air relative humidity during the experiment were $23^{\circ} \mathrm{C}$ and $78 \%$, respectively. The total rainfall in the period was $101 \mathrm{~mm}$. This data were obtained from the INMET-National Institute of Meteorology, collected in the main climatological station of Campina Grande, Paraíba State, Brazil.

Three seeds of three upright genotypes were sowed in pots with capacity of $15 \mathrm{~L}$ of soil and filled with the soil samples cited above. The experiments had a completely randomized $3 \times 3$ factorial design, with five repetitions. The following treatments were adopted: 1- crop without $\mathrm{N}$ fertilization (control); 2- crop with chemical $\mathrm{N}$ fertilization (ammonium sulfate, $0.25 \mathrm{~g} \mathrm{plant}^{-1}$, equivalent to $40 \mathrm{~kg} \mathrm{ha}^{-1}$ of $\mathrm{N}$ ), in a single application at sowing, and 3- Inoculation of Bradyrhizobium SEMIA 6144, $11 \mathrm{~mL}$ at $10^{9}$ cells $\mathrm{mL}^{-1}$ per seed), applying directly to the seeds at sowing.

\section{Bacterial strain and growth conditions}

The commercial Bradyrhizobium strain SEMIA 6144 recommended to inoculant production in peanut was used (MAPA, 2011) and grown in liquid YEM medium (Vincent, 1970) for $4-7$ days at $28^{\circ} \mathrm{C}$ up to the late exponential growth phase with about $10^{9}$ cells $\mathrm{mL}^{-1}$.

\section{Gas exchanges}

IRGA (Infra-Red Gas Analyzer, LI-6400, LI-COR, USA) was used in order to estimate the physiological traits. Leaf gas exchanges of $\mathrm{CO}_{2}, \mathrm{H}_{2} \mathrm{O}$ vapor, net $\mathrm{CO}_{2}$ assimilation, stomatal conductance, transpiration and intercellular $\mathrm{CO}_{2}$ concentration/ambient $\mathrm{CO}_{2}$ concentration ( $\mathrm{Ci} / \mathrm{Ca}$ ) were estimated from $30 \%$ of the plants, for each treatment. The measurements were collected from fully expanded leaves of 70 d-plants, from 9:00 am to 11:00 am. Each variable had three repetitions.

\section{Agronomical traits}

Plants were harvested after 90 days and were naturally dried in the field during 5 days. The following characteristics were evaluated: main stem height, number of nodes/plant, root length, root dry weight, weight of pods/plant and number of pods/plant.

\section{Statistical analysis}

Statistical analyses were performed using the SAS program, version 9.1.3 (SAS/STAT, 2005). Data were submitted to analysis of variance and means were compared by Tukey's test ( $p<0.05$ ).

\section{Results and discussion}

\section{Nodulation and agronomical traits}

The genotypes showed limited responses to N-treatments for most of the evaluated variables, except for NN and PW, that increased in sandy soil (Table 1). Both BR 1 and L7 Bege did not depend on $\mathrm{N}$-source to improve the nodulation, although L7 Bege showed increasing of $31 \%$ and $50 \%$ in pod weight, to Ammonium sulfate and Bradyrhizobium treatments, respectively, when compared to control. However, the cv. BRS Havana resulted in a better response to Bradyrhizobium treatment, showing an increase of $39 \%$ to NN and $48 \%$ to PW, when compared to control.

For $\mathrm{N}$-treatments in medium textured soil, statistical differences were verified for all evaluated characteristics, except for RL (Tables 2 and 3). However, between genotypes the statistic differences were observed only for MSH and NN. The cv. BRS Havana was broadly benefited by the Bradyrhizobium treatment, presenting an increase of $29 \%$ for $\mathrm{MSH}$ and $28 \%$ for NN, comparing to control. The opposite response was verified for BR 1 and L7 Bege that showed, respectively, $10 \%$ and $42 \%$ of reduction in $\mathrm{NN}$ in plants treated with $\mathrm{N}$, suggesting that both genotypes were more responsive to native strains, which are widely distributed throughout soil profiles, while improved isolates remains at the first layers (Santos et al., 2005, Bogino et al., 2008, Lopéz-Garcia et al., 2009). For these genotypes it can be a benefit, since root set is located at the first $30 \mathrm{~cm}$ of the soil depth (Nogueira et al., 2013). 
Despite for nodulation results, the root weight and pod production were improved by $\mathrm{N}$-treatments for all peanut genotypes, especially BRS Havana fertilized with Bradyrhizobium.

Table 1. Agronomical variables for peanut genotypes grown in sandy soil. Main stem height (MSH), root length (RL), root weight (RW), number of nodules (NN), number of pods (NP) and pod weight (PW)

\begin{tabular}{|c|c|c|c|c|c|c|c|c|c|c|}
\hline \multirow{2}{*}{ Genotypes } & \multirow{2}{*}{$\begin{array}{l}\mathrm{MSH} \\
(\mathrm{cm})\end{array}$} & \multirow{2}{*}{$\begin{array}{c}\mathrm{RL} \\
(\mathrm{cm})\end{array}$} & \multirow{2}{*}{$\begin{array}{l}\text { RW } \\
\text { (g) }\end{array}$} & \multicolumn{3}{|c|}{ NN } & \multirow[t]{2}{*}{ NP } & \multicolumn{3}{|c|}{ PW (g) } \\
\hline & & & & $C$ & AS & $\mathrm{BR}$ & & $C$ & AS & BR \\
\hline BR 1 & 13.2 & 17 & $1.3 a b$ & $60 \mathrm{Aa}$ & $18 \mathrm{Cb}$ & $31 \mathrm{Bb}$ & $7.0 a b$ & $3.5 \mathrm{Aa}$ & $3.4 \mathrm{Ab}$ & $3.5 \mathrm{Ab}$ \\
\hline BRS Havana & 12.9 & 18 & $1.3 a b$ & $23 \mathrm{Bb}$ & $15 \mathrm{Cb}$ & $32 \mathrm{Ab}$ & $8.9 a$ & $3.0 \mathrm{Bb}$ & $3.0 \mathrm{BC}$ & $3.8 \mathrm{Ab}$ \\
\hline L7 Bege & 13.3 & 20 & $1.5 a$ & $63 \mathrm{Aa}$ & $51 \mathrm{Ba}$ & $49 \mathrm{Ba}$ & $9.0 a$ & $3.2 \mathrm{Bab}$ & $4.2 \mathrm{AB}$ & $4.8 \mathrm{Aa}$ \\
\hline Mean & 13.1 & 18 & 1.4 & 49 & 28 & 37 & 8.6 & 3.2 & 3.5 & 4.0 \\
\hline CV (\%) & 12.6 & 13.8 & 18.2 & & 26.8 & & 22.9 & & 14.7 & \\
\hline
\end{tabular}

(N-sources) and lowercase letters between genotypes. C: control (no nitrogen), AS: Ammonium sulfate, BR: Bradyrhizobium.

Table 2. Agronomic characteristics for peanut genotypes grown in medium textured soil. Main stem height (MSH), root length (RL) and root weight (RW)

\begin{tabular}{|c|c|c|c|c|c|c|c|}
\hline \multirow{2}{*}{ Genotypes } & \multicolumn{3}{|c|}{$\mathrm{MSH}(\mathrm{cm})$} & \multirow{2}{*}{$\begin{array}{c}\mathrm{RL} \\
(\mathrm{cm})\end{array}$} & \multicolumn{3}{|c|}{ RW (g) } \\
\hline & C & AS & $\mathrm{BR}$ & & C & AS & $\mathrm{BR}$ \\
\hline BR 1 & $26 \mathrm{Aab}$ & $29 \mathrm{Aab}$ & $26 \mathrm{Ab}$ & 63 & $5.8 \mathrm{~B}$ & $6.5 \mathrm{~A}$ & $6.0 \mathrm{AB}$ \\
\hline BRS Havana & $28 \mathrm{Ba}$ & $34 \mathrm{Aa}$ & $36 \mathrm{Aa}$ & 69 & $5.9 \mathrm{~B}$ & $6.3 \mathrm{~A}$ & $6.4 \mathrm{~A}$ \\
\hline L 7 Bege & $26 \mathrm{Bab}$ & $34 \mathrm{Aa}$ & $31 \mathrm{Aab}$ & 68 & $5.7 \mathrm{~B}$ & $6.2 \mathrm{~A}$ & $6.5 \mathrm{~A}$ \\
\hline Mean & 27 & 32 & 31 & 67 & 5.8 & 6.3 & 6.3 \\
\hline CV (\%) & 15.8 & & & 11.9 & 25.1 & & \\
\hline
\end{tabular}

Table 3. Agronomic characteristics for peanut genotypes grown in medium textured soil. Number of nodules (NN), number of pods (NP) and pod weight (PW).

\begin{tabular}{|c|c|c|c|c|c|c|c|c|c|}
\hline \multirow{2}{*}{ Genotypes } & \multicolumn{3}{|c|}{ NN } & \multicolumn{3}{|c|}{ NP } & \multicolumn{3}{|c|}{ PW (g) } \\
\hline & $C$ & AS & $B R$ & $C$ & AS & BR & C & AS & BR \\
\hline BR 1 & $180 \mathrm{AC}$ & $166 \mathrm{BC}$ & 159BC & $24 B$ & $32 \mathrm{~A}$ & $34 \mathrm{~A}$ & $10.3 B$ & $24.8 \mathrm{~A}$ & $26.8 \mathrm{~A}$ \\
\hline BRS Havana & $215 \mathrm{Cb}$ & $258 \mathrm{Ba}$ & $275 \mathrm{Aa}$ & $22 C$ & $29 B$ & $33 \mathrm{~A}$ & $10.1 \mathrm{C}$ & $22.7 \mathrm{~B}$ & $26.6 \mathrm{~A}$ \\
\hline L 7 Bege & $389 \mathrm{Aa}$ & $229 \mathrm{Bb}$ & $225 \mathrm{Bab}$ & $25 \mathrm{C}$ & $31 A B$ & $35 \mathrm{~A}$ & $10.5 B$ & $24.7 \mathrm{~A}$ & $27.6 \mathrm{~A}$ \\
\hline Mean & 261 & 218 & 220 & 24 & 31 & 34 & 10.3 & 24.1 & 27 \\
\hline CV (\%) & 23.6 & & & 21.3 & & & 29.2 & & \\
\hline
\end{tabular}

Santos et al. (2007) reported that peanut has broad capacity of nodulation with native strains presented in sandy and clay loam soils in the semiarid environment. However, this ability is genotype-dependent because the climate may affect directly the non-native rhizobia and restrict the survival and efficiency of the root set in nodulating plants. Studies of interactions between legumes and rhizobia in semiarid environment demonstrated that native strains were more able to fix $\mathrm{N}_{2}$ in conditions that would not be supported by exotic species (Taurian et al., 2006, Ibañez et al., 2008, Ruiz-Díez et al., 2012).

Although there is an availability of exotic species with high efficiency in nitrogen fixation for several legume species, selection of native strains provides perspectives to broad the exploration of new isolates adapted to dry environments, favoring low responsive cultivars to commercial isolates. Nevertheless, it is worth pointing that the soil properties, involving fertility, texture and depth contribute to response of isolates $x$ genotypes. The agronomic responses observed in the present study in medium textured soil were associated to texture, that favored the nutrients retention and soil moisture, and the high organic matter content in the Ultisol. In sandy soils, the leaching of fertilizers due to its texture and the low organic matter content possibly limited the SEMIA 6144 activity.

\section{Physiological evaluation}

No statistical differences were verified according to genotypes and treatments on the physiological traits, excepting for $\mathrm{Ci} / \mathrm{Ca}$ ratio in the medium-textured soil treatment (Table 4). 
The lowest $\mathrm{Ci} / \mathrm{Ca}$ value was observed for BRS Havana in Bradyrhizobium treatment, indicating that the inoculation with SEMIA 6144 contributed to an improvement of the plants photosynthetic efficiency. The cV. BR 1 showed intermediate behavior between BRS Havana and L7 Bege in treatments with ammonium sulfate and Bradyrhizobium.

The $\mathrm{Ci} / \mathrm{Ca}$ ratio is a trait that is directly involved in plant photosynthetic activity. The value can be changed due to variations in the rates of net assimilation and stomatal conductance. Reduced stomatal conductance restricts the $\mathrm{CO}_{2}$ entrance in intercellular areas, which tends to be consumed by the photosynthetic assimilation. Thus, the lower the $\mathrm{Ci} / \mathrm{Ca}$ ratio, the higher the photosynthesis efficiency. In some crops, it may lead to a production increase (Kaschuk et al., 2012).
In literature, some authors reported that the photosynthesis of rhizobial plants increased regardless the lower leaf $\mathrm{N}$ concentration in $\mathrm{N}$ fertilized plants. Kaschuk et al. (2012) compared the photosynthetic capacity of soybean inoculated with two different B. japonicum strains, and observed that nodulated plants had 14-31\% higher rates of photosynthesis and accumulated less starch in the leaves than $\mathrm{N}$-fertilized plants. According to the authors, rhizobial symbiosis stimulated photosynthesis due to the removal of photosynthates sink limitation by the nodule activity. Oliveira et al. (2012) also observed the same results to cowpea, where plants inoculated with a commercial rhizobia strain showed more efficiency on gas exchanges than the control plants. Also, in the present study, peanut presented a better gas exchange behavior when inoculated with SEMIA 6144.

Table 4. Estimated $\mathrm{Ci} / \mathrm{Ca}$ ratio for peanut genotypes grown in medium textured soil experiment.

\begin{tabular}{lccc}
\hline Genotyps & C & AS & BR \\
\hline BR 1 & $0.64 \mathrm{Aa}$ & $0.58 \mathrm{Bab}$ & $0.58 \mathrm{Bab}$ \\
BRS Havana & $0.61 \mathrm{Aa}$ & $0.56 \mathrm{Bb}$ & $0.53 \mathrm{BCb}$ \\
L7 Bege & $0.63 \mathrm{Aa}$ & $0.61 \mathrm{Aa}$ & $0.62 \mathrm{Aa}$ \\
\hline Mean & 0.63 & 0.58 & 0.58 \\
\hline Means followed by the same letter are not statistically different according to Tukey's test at 5\% of probability. Capital \\
letters should be compared between treatments (N-sources) and lowercase letters between genotypes. C: control \\
(no nitrogen), As: Ammonium sulfate, BR: Bradyrhizobium sp. CV $=3.91 \%$
\end{tabular}

\section{Conclusions}

The inoculation of Bradyrhizobium sp. SEMIA 6144 in peanut plants grown in medium textured and sandy soils benefited the nodulation, pod production and gas exchanges of BRS Havana cultivar. For other cultivars, it is necessary to incorporate the BNF in breeding programs in order to identify responsive isolates that can increase plant development.

\section{Acknowledgements}

TO REPENSA (National Network for Research on Agricultural Biodiversity and Sustainability - MCT/ CNPq/ MEC/ CAPES/ CT AGRO/ CT IDRO/ FAPS/ EMBRAPA), for the financial support and to CAPES, for the grants.

\section{References}

Ahemad, M., Kibret, M. 2014. Mechanisms and applications of plant growth promoting rhizobacteria: Current perspective. Journal of King Saud University Science 26:1-20.
Angelini, J., Ibáñez, F., Taurian, T., Tonelli, M.L., Valetti, L., Fabra, A. 2011. A study on the prevalence of bacteria that occupy nodules within single peanut plants. Current Microbiology 62:1752-1759.

Bogino, P., Banchio, E., Bonfiglio, C., Giordano, W. 2008. Competitiveness of Bradyrhizobium sp. strain in soils containing indigenous rhizobia. Current Microbiology Heidberg 56: 66-72.

Bolonhezi, D., Godoy, I.J., Santos, R.C. 2013. Manejo cultural do amendoim. In: Santos, R.C., Freire, R.M.M., Lima, L.M. (eds.) O Agronegócio do amendoim no Brasil. Embrapa, Brasília, Brasil. p. 185-237.

Borges, W.L., Silva, C.E.R., Xavier, G.R., Rumjanek, N.G. 2007. Nodulação e fixação biológica de nitrogênio de acessos de amendoim com estirpes nativas de rizóbios. Revista Brasileira de Ciências Agrárias 2: 32-37.

Epstein, E. Bloom, A.J. 2006. Nutrição Mineral das plantas. Planta, Londrina, Brasil. 403 p.

EMBRAPA. 2013. Empresa Brasileira de Pesquisa Agropecuária. Sistema brasileiro de classificação 
de solos. 3 ed. rev. ampl. Embrapa, Brasília, Brasil. $353 p$.

Hayat, R., Ali, S., ljaz, S.S., Chatha, T.H., Siddique M.T. 2008. Estimation of $\mathrm{N}_{2}$-fixation of mung bean and mash bean through xylem uriede technique under rainfed conditions. Pakistan Journal of Botany 40: 723-734.

Ibañez, F., Taurian, T., Angelini, J., Tonelli, M.L., Fabra, A. 2008. Rhizobia phylogenetically related to common bean symbionts Rhizobium giardinii and Rhizobium tropici isolated from peanut nodules in Central Argentina. Soil Biology and Biochemistry 40: 537-539.

Jones, K.M., Kobayashi, H., Davies, B.W., Taga, M.E., Walker, G.C. 2007. How rhizobial symbionts invade plants: the Sinorhizobium-Medicago model. Nature Reviews Microbiology 5: 619-633.

Kaschuk, G., Yin, X., Hungria, M., Leffelaar, P.A. Guiller, K.E., Kuyper, T.W. 2012. Photosynthetic adaptation of soybean due to varying effectiveness of $\mathrm{N}_{2}$ fixation by two distinct Bradyrhizobium japonicum strains. Environment Experimental Botanic 76: 1-6.

Lopéz-Garcia, S.L., Perticari, A., Piccinetti, C., Ventimiglia, L., Arias, N., De Battista, J.J., Althabegoiti, M.J., Mongiardini, E.J., PérezGiménez, J., Quelas, J.I., Lodeiro, A.R. 2009. In-furrow inoculation and selection for higher motility enhances the efficacy of Bradyrhizobium japonicum nodulation. Agronomy Journal 101: 357-363.

Lyra, M.C.C.P., Freitas, A.D.S., Silva, T.M., Santos, C.E.R.S. 2013. Phenotypic and molecular characteristics of rhizobia isolated from nodules of peanut (Arachis hypogaea L.) grown in Brazilian Spodosols. African Journal of Biotechnology 12: 2147-2156.

MAPA. Ministério da Agricultura, Pecuária e Abastecimento. 2011. https ://www.inoleg.dcs. ufla.br/index.php/downloads\%3F3...+\&ie=utf$8 \& 0 e=u t f-8 \& g w s \_r d=c r \& e i=0$ Ayy $V r m 4 H$ Mqseceg sKgL/<Acess: Dec, 16 2015>.

Montans, F.M., Costa, A.F., Guimarães, A.M., Oliveira, P.S.R. 2008. Aplicação de inoculante, cobalto e molibdênio em amendoim cultivados em solos de diferentes texturas. Unimar Ciências 17: 29-33.

Nehra, K., Yadav, A.S., Sehrawat, A., Vashishat, R.K. 2007. Characterization of heat resistant mutant strains of Rhizobium sp. (Cajanus) for growth, survival and symbiotic properties. Indian Journal Microbiology 47: 329-335.

Nogueira, R.J.M.C., Távora, F.J.A.F., Albuquerque, M.B. de, Nascimento, H.H.C. do, Santos, R.C. dos. 2013. Ecofisiologia do amendoim (Arachis hypogaea L). In: Santos, R.C., Freire, R.M.M., Lima, L.M. (eds.) O Agronegócio do amendoim no Brasil. Embrapa, Brasília, Brasil. p. 70-113.

Oliveira, M.T., Benko-Iseppon, A.M., Kido, E.A., Santos, M.G. 2012. Leaf photosynthetic metabolism and $\mathrm{N}_{2}$ fixation at the flowering stage in three genotypes of cowpea [Vigna unguiculata (L.) Walp.]. Journal of Agricultural Sciences 4: 245-256.

Ruiz-Díez, B., Fajardo, S., Fernández-Pascual, M. 2012. Selection of rhizobia from agronomic legumes grown in semiarid soils to be employed as bioinoculants. Agronomy Journal 104: 550-559.

SAS/STAT User's Guide. 2005. In: SAS Institute. SA ${ }^{\mathrm{S}}$ Onlindoc: version 9.1.3, Cary, North Carolina.

Santos, C.E.R.S., Stamford, N.P., Freitas, A.D.S., Vieira, I.M.M.B., Souto, S.M., Neves, M.C.P., Rumjanek, N.G. 2005. Efetividade de rizóbios isolados de solos da região Nordeste do Brasil na fixação do $\mathrm{N}_{2}$ em amendoim (Arachis hypogaea L.). Acta Scientiarum - Biological Sciences 27: 301-307.

Santos, C.E.R.S., Stamford, N.P., Borges, W.L., Rumjanek, N.G., Nascimento, L.R., Freitas, A.D.S., Vieira, I.M.M.B., Bezerra, R.V. 2007. Faixa hospedeira de rizóbios isolados das espécies de Arachis hypogaea, Stylosanthes guyanensis e Aeschynomene americana. Revista Brasileira de Ciências Agrarias 2: 20-27.

Santos, R.C., Queiroz, C.M., Batista, V.G. L., Silva, C.R. C., Pinheiro, M.P.N., Galvão Filho, A.L.A., Melo Filho, P.A., Lima, L.M. 2013. Variability of F2 peanut progenies generated through the selection of ISSR-divergent genitors. Revista Ciência Agronômica 44: 578-586.

Siddique, A.M., Bal, A.K. 1991. Nitrogenase fixation in peanut nodules during dark periods and detopped conditions with special reference to lipid bodies. Plant Physiology 95: 896-899.

Swain, H., Abhiijta, A. 2013. Nitrogen fixation and its improvement through genetic engineering. Journal of Global Biosciences 2: 98-112.

Taurian, T., Ibañez, F., Fabra, A., Aguilar, O. 2006. Genetic diversity of rhizobia nodulating Arachis hypogaea L. in Central Argentinean soils. Plant and Soil 282: 41-52.

Torres-Júnior, C.V., Leite, J., Santos, C.E.R.S., Fernandes-Júnior, P.I., Zilli, J.E., Rumjanek, N.G., Xavier, G.R. 2014. Diversity and symbiotic performance of peanut rhizobia from Southeast region of Brazil. African Journal of Microbiology Research 8: 566-577.

Vincent, J.M. 1970. A manual for the practical study of root nodule bacteria. Blackwell Scientific 
Publication. Oxford, England. 164p.

Yadav, A.S., Nehra, K. 2013. Selection/Isolation of High Temperature Tolerant Strains of Rhizobium for Management of High Temperature Stress on Rhizobium- Legume Symbiosis. International Journal of Microbial Resource 